\title{
Characteristics and Environmental Factors of Stoichiometric Homeostasis of Soil Microbial Biomass Carbon, Nitrogen and Phosphorus in China
}

\author{
Haili Xue ${ }^{1,2,3}$, Xiao Lan ${ }^{1,3, *}$, Haoguang Liang ${ }^{1,3}$ and Qin Zhang ${ }^{1,4}$ \\ 1 Beijing Key Laboratory of Belt and Raod's Data Analysis and Decision Support, \\ China Academy of the Belt and Road Initiative, Beijing International Studies University, Beijing 100024, \\ China; 20180026@bisu.edu.cn (H.X.); lhg@bisu.edu.cn (H.L.); 201631190011@mail.bnu.edu.cn (Q.Z.) \\ 2 College of Business Administration, Capital University of Economics and Business, Beijing 100070, China \\ 3 Beijing Advanced Innovation Center for Language Resources, Beijing Language and Culture University, \\ Beijing 100083, China \\ 4 State Key Laboratory of Earth Surface Processes and Resource Ecology, Faculty of Geographical Science, \\ Beijing Normal University, Beijing 100875, China \\ * Correspondence: 20180029@bisu.edu.cn; Tel.: +86-10-6577-8676
}

Received: 12 March 2019; Accepted: 30 April 2019; Published: 16 May 2019

check for updates

\begin{abstract}
Marine studies have shown that the carbon:nitrogen:phosphorus (C:N:P) atomic ratio in planktonic organisms is generally 106:16:1, which is known as the "Redfield ratio". This raises the question of whether there are similar patterns in terrestrial organisms, particularly in soil. In this study, we extracted 404 datasets from the literature to analyze the ecological stoichiometry of C, $\mathrm{N}$ and $\mathrm{P}$, both in the soil and in the soil microbial biomass in China; additionally, we assessed their relationships with environmental factors, and calculated the homeostasis coefficient $(H)$ of soil microbial biomass. First, although the concentrations of $\mathrm{C}, \mathrm{N}$ and $\mathrm{P}$ in soil and soil microbial biomass showed high spatial heterogeneity, the atomic C:N:P ratios in the soil and soil microbial biomass were relatively consistent at the national scale. Second, the influences of temperature and precipitation on stoichiometric relationships among $\mathrm{C}, \mathrm{N}$ and $\mathrm{P}$ in the soil and soil microbial biomass were limited in China; however, they decreased with the increase in soil $\mathrm{pH}$. Third, the degree of stoichiometric homeostasis for soil microbes spanned a wide range, from non-homeostasis to strict homeostasis. For single elements, most of the soil microbes' $H$ ranged from 1.01 to 5.00; for elemental ratios, most of the soil microbes' $H$ displayed strict homeostasis. This study indicates that the "Redfield-like" ratio exists in the soil microbial biomass in the $0-20 \mathrm{~cm}$ soil layer in China, with an atomic C:N:P ratio of $66: 8: 1$ and it is close to the atomic C:N:P ratio in the soil (66:5:1) of terrestrial ecosystems. In addition to the N:P ratio in plants, the soil microbial biomass N:P ratio may also be used to judge the nutrient limitations because of its high stability.
\end{abstract}

Keywords: stoichiometric; China terrestrial ecosystems; homeostasis; Redfield-like ratio; biomes

\section{Introduction}

Chemical elements, including carbon $(\mathrm{C})$, nitrogen $(\mathrm{N})$ and phosphorus $(\mathrm{P})$, and their composition comprise an important foundation of biological and ecological systems (Schimel, 2003). An important reference about the $\mathrm{C}, \mathrm{N}$ and $\mathrm{P}$ ecological stoichiometry is the study of oceanic ecosystems [1]. According to the data from numerous regions of the world's oceans, Alfred Redfield unexpectedly discovered the C:N:P ratio on the atomic basis in marine organisms was well constrained, a value known as the "Redfield ratio". Specifically, the study indicated that the close reciprocal relationship between the ocean environment and marine organisms regulated the concentrations of $\mathrm{C}, \mathrm{N}$ and $\mathrm{P}$, and formed 
the constrained C:N:P ratio in marine particulate matter (106:16:1). The ratio is of great significance for the study of global biogeochemical systems, and provides valuable insights into the study of biogeochemical nutrient (N, P) cycles in the oceans [2]. The significance of the "Redfield ratio" raises the question of whether there is a similar stoichiometric relationship, a "Redfield-like" ratio, in soil and terrestrial organisms, and this question also has inspired a new discipline, ecological stoichiometry, which studies the balance of multiple chemical substances in ecological interactions and processes [3]. Ecological stoichiometry can simplify the study of the N, P biogeochemical cycling and calculation of the energy flux. However, due to the heterogeneity and complexity of terrestrial ecosystems (such as soil parent material, topography, climate, developmental stage and biological diversity), it still remains unclear what the soil ecological stoichiometry characteristics are and whether a stable elemental ratio exists. In recent years, some studies have indicated that a "Redfield-like" ratio does exist in soil and plants in terrestrial ecosystems [4-9]. For soil microbial biomass elements however, the stoichiometric pattern and mechanism remains unclear. The soil microbes are characterized by more complexity and diversity when compared to marine ecosystems and plants, but a previous study indicates that the mass $\mathrm{C}: \mathrm{N}$ ratio of the microbial biomass is constrained, with the values ranging from 8:1-12:1 [10]. Moreover, to our knowledge, there have been few efforts to assess the characteristics of soil microbial biomass $\mathrm{C}, \mathrm{N}$ and $\mathrm{P}$ stoichiometry, the representative studies basically focus on the global pattern of soil microbial stoichiometry. Cleveland and Liptzin (2007) collected 186 data points at the global scale, and discovered that the $\mathrm{C}: \mathrm{N}: \mathrm{P}$ atomic ratio of soil microbial biomass is relatively consistent, with a value of 60:7:1 [4]. Later, Xu et al. (2013) collected 3422 data points at the global scale, and suggest that there is a "Redfield-like" ratio in soil microbial biomass, with a value of 42:6:1 [7]. Li et al. (2014) studied the factors that were likely to influence the N:P stoichiometry in global forest ecosystems, and stated that the pattern of soil microbial biomass elemental ratio's stoichiometry was influenced by the edaphic variables (soil $\mathrm{N}$ concentration, $\mathrm{P}$ concentration, $\mathrm{pH}$ value) [8]. The pattern and mechanism of soil microbial biomass elements remain unclear, and the studies are based on the global scale, reporting limited data from China. Therefore, further studies are necessary to understand the stoichiometric relationships of $\mathrm{C}, \mathrm{N}$ and $\mathrm{P}$ in the soil microbial biomass at national and biome scales in China.

Stoichiometric homeostasis, i.e., an organism maintains a given elemental composition despite variation in the elemental composition of its resource supplies, is regarded as a core concept of ecological stoichiometry [3]. Stoichiometric homeostatic regulation can reflect the effect of soil environments on soil microbial biomass, and it is an important mechanism to understand the variation of soil microbial C:N:P stoichiometry [11]. The regulation coefficient $(H)$ is used to express the degree of stoichiometric homeostasis, which can be quantified by a linearized regression through $\mathrm{C}, \mathrm{N}$ and $\mathrm{P}$ concentrations in organisms and environment. Theoretically, for the values of $H$ there exists two extremes, i.e., strict homeostasis and non-homeostasis (see Figure 1).

There have been considerable efforts to quantify the $H$ values of organisms, covering the $H$ of animals, plants, bacteria, fungi and algae [12-16]. However, little attention has been paid to investigating the homeostasis of soil microbial biomass. Demott and Pape (2005) indicate that the $H$ values of zooplankton are strong, ranging from 4 to 40 [17], and the average $H_{\mathrm{C}}, H_{\mathrm{N}}$ and $H_{\mathrm{P}}$ of zooplankton were 13.8, 34.1 and 7.7, respectively, indicating that the $H$ values differ among different elemental types [14]; in addition, the $H_{\mathrm{C}: \mathrm{P}}$ values of Daphnia range from 16 to 161 , which is higher than that of a single element [15]. The $H_{\mathrm{N}: \mathrm{P}}$ of herbaceous plants ranges from 1.7 to 4.6 [18], and work on vascular plants shows that the values of $H_{\mathrm{N}}, H_{\mathrm{P}}$ and $H_{\mathrm{N}: \mathrm{P}}$ range from 1.93 to 14.5 [6]. The $H$ of algae or fungi was weak, with the values ranging from 1 to 2 [12], while most of the bacteria's $H$ were less than 6 , despite a small portion with an especially large $H$ [13]. For soil microbes, to our knowledge, there are few studies that ever have analyzed the homeostatic characteristics of soil microbial C:N:P at the national scale, nor quantified the stoichiometric homeostasis of soil microbial biomass. 


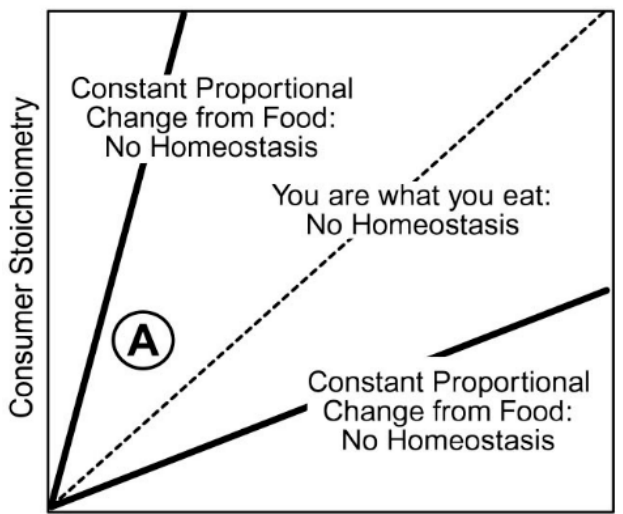

Resource Stoichiometry

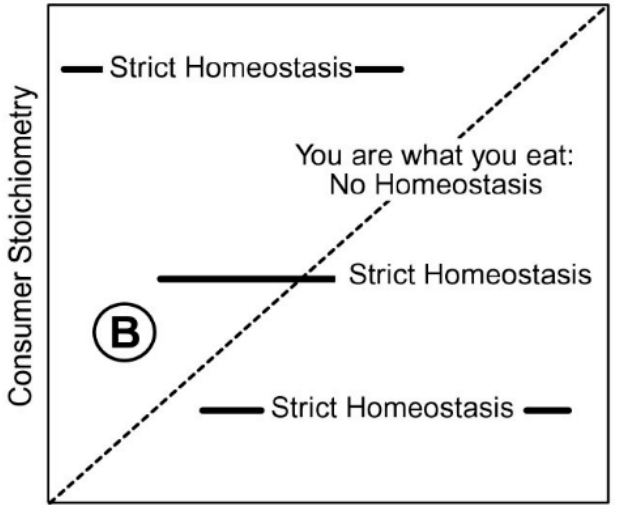

Resource Stoichiometry

Figure 1. Generalized stoichiometric patterns relating consumer stoichiometry to resource stoichiometry. Dotted line (slope 1 , intercept $=0$ ) represent identical stoichiometry in resources and consumer. In part of $\mathrm{A}$, the dashed line represents a consumer with stoichiometry that always matches the stoichiometry of its resources. In In part of B, the dashed line represents strict homeostasis (slope 0, intercept $>0$ ). Cited from Sterner and Elser (2002).

Focusing on stoichiometric relationships and the homeostasis of soil microbial biomass $\mathrm{C}, \mathrm{N}$ and $\mathrm{P}$, both at national and biome scales in China, we extracted soil and microbial biomass $\mathrm{C}, \mathrm{N}$ and $\mathrm{P}$ data from the literature to (1) determine whether a "Redfield-like" ratio exists for soil microbial biomass $\mathrm{C}: \mathrm{N}: \mathrm{P}$ in China's terrestrial ecosystems, (2) identify the relationship between environmental factors and $\mathrm{C}, \mathrm{N}$ and $\mathrm{P}$ (as single elements and their ratios) in the soil and soil microbial biomass, and (3) analyze the characteristics of the homeostasis of soil microbial biomass $\mathrm{C}, \mathrm{N}$ and $\mathrm{P}$ as single elements and their ratios.

\section{Materials and Methods}

\subsection{Data Sources}

We selected relevant academic publications by searching for "microbial biomass carbon", "microbial biomass nitrogen", "microbial biomass phosphorus", "microbial C", "microbial N" and "microbial P" using the China National Knowledge Infrastructure (http://www.cnki.net/) and ISI Web of Science (http://isiknowledge.com/, we specifically filtered articles to find research that focused on work completed in China). A total of 404 datasets were retrieved from 170 papers (Appendix A, most papers were published in Chinese with an English abstract). The selected papers were typically those where the research had sampling depths focused on the surface layer, i.e., $0-20 \mathrm{~cm}$, with a small number of datasets including soil to a depth of $30 \mathrm{~cm}$. According to the descriptions provided in the papers, we categorized the datasets into six biomes: grassland (91), forest (122), cropland (157), desert (18), wetland (14) and bare land (2). From these selected papers, we also extracted the data on soil C, N, P, geographical coordinates and $\mathrm{pH}$ values.

When selecting the published literature, we adopted the following three criteria to avoid bias: first, at least one of soil C, N or P and the corresponding soil microbial biomass $\mathrm{C}, \mathrm{N}$ or P must have been reported. Second, we only cited the published literature in which the method of chloroform fumigation extraction was adopted to determine the microbial biomass content. Third, we only cited the data that were determined by field-fresh soil samples which were free of fertilization tests in cropland.

\subsection{Calculation of Homeostatic Coefficients}

We calculated the degree of homeostasis of soil microbial biomass $\mathrm{C}, \mathrm{N}, \mathrm{P}$ and elemental ratios in grassland, forest, cropland, desert and wetland (there were only two sets of data in bare land, so we 
did not calculate the degree of homeostasis in bare land). The degree of stoichiometric homeostasis is quantified by the homeostasis coefficient $(H)$, which is calculated by a linearized equation [3]:

$$
\log (y)=\log (c)+\frac{\log (x)}{H}
$$

where $y$ refers to the soil microbial biomass atomic concentrations of $C, N, P$ or the elemental atomic ratios; $x$ refers to soil $C, N$ and $P$ or the soil elemental atomic ratios in each biome; and $c$ is a constant. We cited the $H$ categories of Persson et al. (2010) that if the linear regression was not significant $(p>0.1)$ [19], the organism was considered "strictly homeostatic". All datasets with significant regressions were arbitrarily classified as $H \geq 4$ : "homeostasis", $2 \leq H<4$ : "weakly homeostatic", $1.33 \leq H<2$ : "weakly plastic", and $H<1.33$ : "plastic". $H \leq 1$ indicated non-homeostasis, and higher $H$ values indicated stronger homeostasis of either the soil microbial biomass $\mathrm{C}, \mathrm{N}$ and $\mathrm{P}$ or the elemental ratios.

\subsection{Statistical Analysis}

All data were stored in Microsoft Excel, which was used to calculate the concentrations of $\mathrm{C}, \mathrm{N}$ and $\mathrm{P}$, as well as the C:N, C:P and N:P atomic ratios; the raw data were assessed through chemical analysis, and the analysis of the data of the concentrations of $\mathrm{C}, \mathrm{N}, \mathrm{P}$ and the C:N:P ratios were all on the atomic basis:

$$
\text { Atomic Number Ratio }=\text { Mass ratio/Atomic Weight Ratio }
$$

The atomic weights of $C, N$ and $P$ were $12.0107,14.00674$ and 30.973762, respectively. In addition, the C, N, P and C:N:P ratios mentioned below are the atomic concentrations and atomic ratios, respectively.

Prior to all analyses, nutrient ratios were $\log _{10}$ transformed to improve the distribution and homogeneity of variance. We used IBM SPSS Statistics 19.0 to conduct the statistical analysis and Sigma Plot 10.0 to draw the figures. The bilateral alternative (two-tailed) $t$-test was used to compare the mean values between two independent samples. For multiple comparisons of mean values among three or more samples, analysis of variance (ANOVA) was used, and different methods adopted according to whether the variances are homogenous or not. Therefore, we first tested the homogeneity of variance using Levene's test, if the variances were homogenous, ANOVA with the Duncan's post hoc test were used, if not, ANOVA with the Tamhane's $T_{2}$ methods were used. The significances of both the linear regression and the polynomial regression were obtained by ANOVA for the $F$ statistic and $p$ value.

\section{Results}

\subsection{Concentrations of $C, N$ and $P$ in the Soil and Soil Microbial Biomass}

At the national scale, the average concentrations of soil C, N and P were $1046.7 \mathrm{mmol} \mathrm{kg}^{-1}$, $109.8 \mathrm{mmol} \mathrm{kg}^{-1}$ and $23.0 \mathrm{mmol} \mathrm{kg}$, respectively. The average concentrations of soil microbial biomass $\mathrm{C}, \mathrm{N}$ and $\mathrm{P}$ were $26.3 \mathrm{mmol} \mathrm{kg}-1,3.4 \mathrm{mmol} \mathrm{kg}^{-1}$ and $0.6 \mathrm{mmol} \mathrm{kg}^{-1}$, respectively (see Table 1). At the biome scale, the concentrations of $\mathrm{C}, \mathrm{N}$ and $\mathrm{P}$ differed within different biome types both in terms of soil and soil microbial biomass; however, these differences displayed the same pattern. Wetland had the highest concentrations of soil C, N and P, with values of $2225.6 \mathrm{mmol} \mathrm{kg}-1,185.6 \mathrm{mmol} \mathrm{kg}^{-1}$ and $56.2 \mathrm{mmol} \mathrm{kg}^{-1}$, respectively, and wetland also had the highest concentrations of soil microbial biomass $\mathrm{C}, \mathrm{N}$ and $\mathrm{P}$, with values of $65.4 \mathrm{mmol} \mathrm{kg}-1,7.4 \mathrm{mmol} \mathrm{kg}^{-1}$ and $1.1 \mathrm{mmol} \mathrm{kg}^{-1}$, respectively. While bare land had the lowest concentrations of soil $\mathrm{C}$ and $\mathrm{N}$, with values of $77.4 \mathrm{mmol} \mathrm{kg}^{-1}$ and $27.12 \mathrm{mmol} \mathrm{kg}^{-1}$, respectively, bare land also had the lowest concentrations of soil microbial biomass $\mathrm{C}$, $\mathrm{N}$ and $\mathrm{P}$, with values of $2.0 \mathrm{mmol} \mathrm{kg}^{-1}, 0.5 \mathrm{mmol} \mathrm{kg}^{-1}$ and $0.02 \mathrm{mmol} \mathrm{kg}^{-1}$, respectively (see Table 1). 
Table 1. Concentrations of $\mathrm{C}, \mathrm{N}$ and $\mathrm{P}$ in the soil and soil microbial biomass in different biomes in China.

\begin{tabular}{|c|c|c|c|c|c|c|}
\hline Biomes & Corg (mmol kg $\left.{ }^{-1}\right)$ & Ntot $\left(\mathrm{mmol} \mathrm{kg} \mathbf{~}^{-1}\right)$ & Ptot $\left(\mathrm{mmol} \mathrm{kg}^{-1}\right)$ & Cmic (mmol kg-1) & Nmic (mmol kg $\left.{ }^{-1}\right)$ & Pmic $\left(\mathrm{mmol} \mathrm{kg}^{-1}\right)$ \\
\hline Grassland & $1204.2^{b c}(1007.7-2371.7)$ & $127.0^{\mathrm{b}}(103.0-151.1)$ & $20.2^{\mathrm{b}}(14.7-25.7)$ & $29.1^{\mathrm{b}}(25.4-32.7)$ & $3.3^{b}(2.9-3.8)$ & $0.6^{\mathrm{b}}(0.4-0.9)$ \\
\hline Forest & $952.7^{\mathrm{ab}}(1161.9-1669.3)$ & $127.6^{\mathrm{b}}(106.0-150.5)$ & $18.8^{\mathrm{b}}(15.9-21.6)$ & $33.6^{\mathrm{b}}(28.9-38.4)$ & $4.1^{\mathrm{b}}(3.6-4.7)$ & $0.7^{\mathrm{b}}(0.5-0.9)$ \\
\hline Cropland & $1021.4^{\mathrm{c}}(963.5-1154.9)$ & $91.5^{\text {c }}(83.1-100.0)$ & $22.3^{\mathrm{b}}(20.0-24.5)$ & $16.8^{\mathrm{c}}(15.2-18.4)$ & $2.6^{\mathrm{c}}(2.3-3.0)$ & $0.3^{\mathrm{b}}(0.2-0.5)$ \\
\hline Desert & $391.8^{d}(220.9-562.7)$ & $31.8^{\mathrm{d}}(18.1-45.46)$ & $11.6^{\mathrm{c}}(7.3-15.9)$ & $9.8^{d}(6.7-12.8)$ & $1.5^{\mathrm{d}}(1.0-2.0)$ & - \\
\hline Wetland & $2225.6^{\text {a }}(1639.3-2371.7)$ & $185.6^{\mathrm{a}}(145.1-226.0)$ & $56.2^{\mathrm{a}}(31.1-81.4)$ & $65.4^{\mathrm{a}}(42.9-87.9)$ & $7.4^{\mathrm{a}}(4.2-10.6)$ & $1.1^{\mathrm{a}}(0.6-1.5)$ \\
\hline Bare land & 77.4 & 27.12 & - & 2.0 & 0.5 & 0.03 \\
\hline Average & 1046.7 (972.1-1121.4) & $109.8(100.5-119.2)$ & $23.0(20.0-26.1)$ & $26.3(24.1-28.6)$ & $3.4(3.1-3.6)$ & $0.6(0.5-0.7)$ \\
\hline
\end{tabular}

Values are presented as means with $95 \%$ confidence boundaries in parentheses. Different superscript letters in one column mean significant difference at a significance level of $p=0.05$, while the same letters indicate no significant difference. Corg, soil organic carbon; Ntot, soil total nitrogen; Ptot, soil total phosphorus; Cmic, soil microbial biomass carbon; Nmic, soil microbial biomass nitrogen; Pmic, soil microbial biomass phosphorus. 


\subsection{Ratios of $C, N$ and $P$ in the Soil and Soil Microbial Biomass}

At the national scale, the average soil C:N, C:P, N:P and C:N:P ratios were 12.2, 62.8, 5.4 and 66:5:1, respectively. The average soil microbial biomass $C: N, C: P, N: P$ and $C: N: P$ ratios were 8.7, 64.0, 7.6 and 66:8:1, respectively (see Table 2). Although the concentrations of soil microbial biomass $C, N$ and $P$ varied at the biome scale, there were no significant differences in soil microbial biomass $C: N, C: P$ and $\mathrm{N}: \mathrm{P}$ ratios among the five biomes (excluding bare land) $(p>0.05)$. In contrast, the soil C:P and N:P ratios showed a slight difference among biomes (see Table 2). The soil and soil microbial biomass $\mathrm{C}: \mathrm{N}, \mathrm{C}: \mathrm{P}$ and N:P ratios were all normally distributed. The soil C:N, C:P and N:P ratios were mostly distributed in the ranges of 8-32, 16-64 and 1-16, respectively; and soil microbial biomass C:N, C:P and $\mathrm{N}: \mathrm{P}$ ratios were mostly distributed in the ranges of 4-16, 16-64 and 2-16, respectively (see Figure 2).

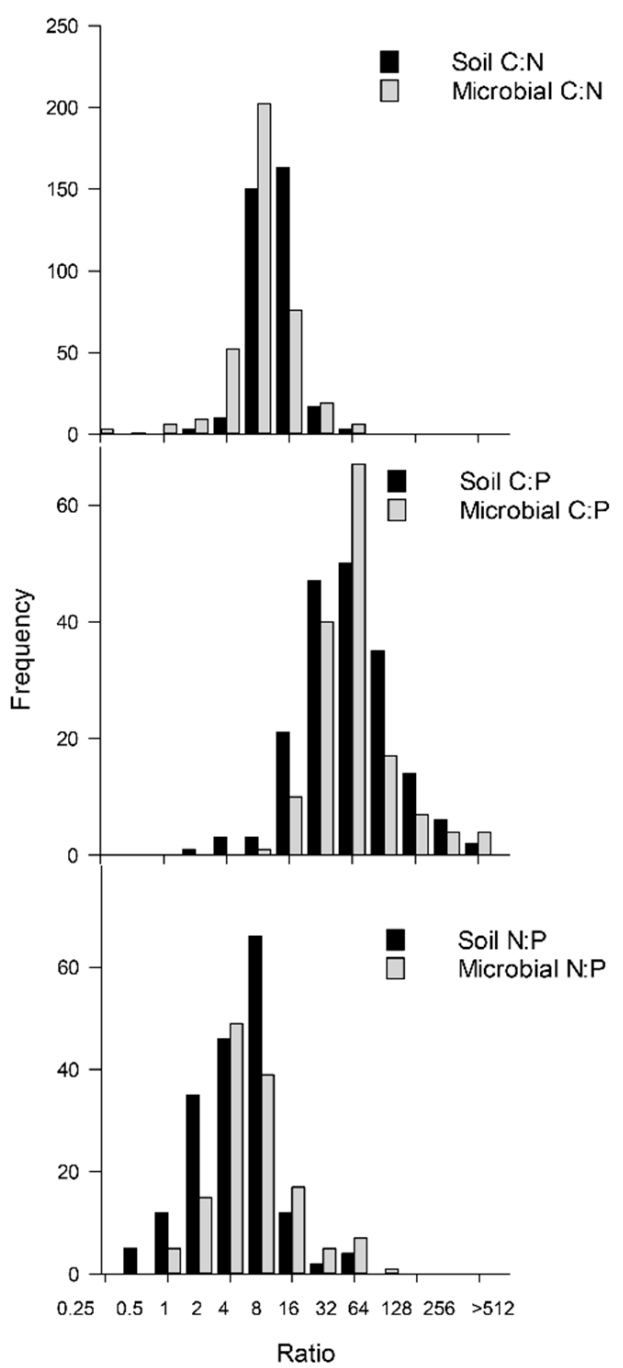

Figure 2. Frequency distribution of nutrient ratios $(\mathrm{C}: \mathrm{N}, \mathrm{C}: \mathrm{P}, \mathrm{N}: \mathrm{P})$ in the soil and in the soil microbial biomass. The data were $\log _{2}$ transformed to improve the lognormal distribution. 
Table 2. Summarized atomic C:N, C:P and N:P ratios and C:N:P stoichiometry for soil elements and soil microbial biomass in different biomes in China.

\begin{tabular}{|c|c|c|c|c|c|c|c|c|}
\hline \multirow{2}{*}{ Biomes } & \multicolumn{3}{|c|}{ Soil Elements } & \multicolumn{4}{|c|}{ Soil Microbial Biomass } & \multirow[b]{2}{*}{$C: N: P$} \\
\hline & $\mathrm{C}: \mathrm{N}$ & $\mathrm{C}: \mathrm{P}$ & $\mathbf{N}: \mathbf{P}$ & $\mathrm{CC}: \mathrm{N}: \mathrm{P}$ & CC:N & $\mathrm{CC}: \mathrm{P}$ & $\mathbf{N N}: \mathbf{P}$ & \\
\hline Grassland & $12.1^{\mathrm{a}}(11.3-12.9)$ & $78.0^{\text {a }}(47.7-108.3)$ & $6.5^{\mathrm{a}}(4.7-8.0)$ & $85: 7: 1$ & $9.5^{\mathrm{a}}(8.4-10.6)$ & $86.7^{\mathrm{a}}(49.8-123.7)$ & $8.2^{\mathrm{a}}(5.2-11.2)$ & $78: 8: 1$ \\
\hline Forest & $13.5^{\mathrm{a}}(12.5-14.5)$ & $61.3^{\mathrm{ab}}(42.5-80.0)$ & $4.8^{\mathrm{ab}}(3.8-5.7)$ & $68: 5,1$ & $8.3^{\mathrm{a}}(7.8-8.9)$ & $54.2^{\mathrm{a}}(47.6-60.8)$ & $6.0^{\mathrm{a}}(5.2-6.8)$ & $50: 6: 1$ \\
\hline Cropland & $11.2^{\text {a }}(10.8-11.7)$ & $60.2^{\mathrm{ab}}(52.9-67.5)$ & $5.4^{\mathrm{ab}}(4.7-6.2)$ & $60: 5: 1$ & $8.7^{\mathrm{a}}(8.0-9.3)$ & $65.8^{\text {a }}(56.7-75.0)$ & $9.4^{\mathrm{a}}(6.4-12.5)$ & 82:9:1 \\
\hline Desert & $13.0^{\text {a }}(11.7-14.3)$ & $45.7^{\mathrm{b}}(31.1-60.4)$ & $4.1^{\mathrm{b}}(2.6-5.5)$ & $46: 4: 1$ & $8.1^{\mathrm{a}}(6.0-10.2)$ & - & - & - \\
\hline Wetland & $11.3^{\mathrm{a}}(10.0-12.7)$ & $68.1^{\mathrm{ab}}(43.5-92.6)$ & $5.9^{\mathrm{ab}}(3.8-8.0)$ & $67: 6: 1$ & $8.8^{\mathrm{a}}(6.4-11.1)$ & $55.6^{\text {a }}(43.9-67.3)$ & $6.4^{\mathrm{a}}(4.6-8.1)$ & $56: 6: 1$ \\
\hline Bare land & 2.4 & - & - & - & 4.1 & - & - & - \\
\hline Average & $12.2(11.7-12.8)$ & $62.8(54.8-70.6)$ & $5.4(4.8-6.0)$ & $66: 5: 1$ & $8.7(8.3-9.1)$ & $64.0(56.2-71.9)$ & $7.6(6.4-8.7)$ & $66: 8: 1$ \\
\hline
\end{tabular}

Values are presented as means with $95 \%$ confidence boundaries in parentheses. Different superscript letters in one column mean significant difference at a significance level of $p=0.05$, while the same letters indicate no significant difference. 
The C:N, C:P, N:P and C:N:P ratios both in the soil and soil microbial biomass were constrained (see Figure 2; Table 2), which indicated that the "Redfield-like" ratio existed for both the soil and the soil microbial biomass C:N:P in terrestrial ecosystems in China. The correlation coefficient of soil C and $\mathrm{N}\left(R^{2}=0.80\right)$ was greater than that of both $\mathrm{C}$ and $\mathrm{P}\left(R^{2}=0.02\right)$ and $\mathrm{N}$ and $\mathrm{P}\left(R^{2}=0.04\right)$, which indicated that the coupling between soil $\mathrm{C}$ and $\mathrm{N}$ was strong, while the coupling between soil $\mathrm{C}$ and $\mathrm{P}$ and between soil $\mathrm{N}$ and $\mathrm{P}$ were both weak. The correlation coefficient of soil microbial biomass $\mathrm{C}$ and $\mathrm{P}\left(R^{2}=0.61\right)$ and the correlation coefficient of $\mathrm{N}$ and $\mathrm{P}\left(R^{2}=0.55\right)$ were both greater than that of $\mathrm{C}$ and $\mathrm{N}\left(R^{2}=0.51\right)$, which also indicated that the coupling of soil microbial biomass $\mathrm{C}$ and $\mathrm{P}$ and soil microbial biomass $\mathrm{N}$ and $\mathrm{P}$ were both stronger than that of soil $\mathrm{C}$ and $\mathrm{P}$ and soil $\mathrm{N}$ and $\mathrm{P}$ (see Figure 3).
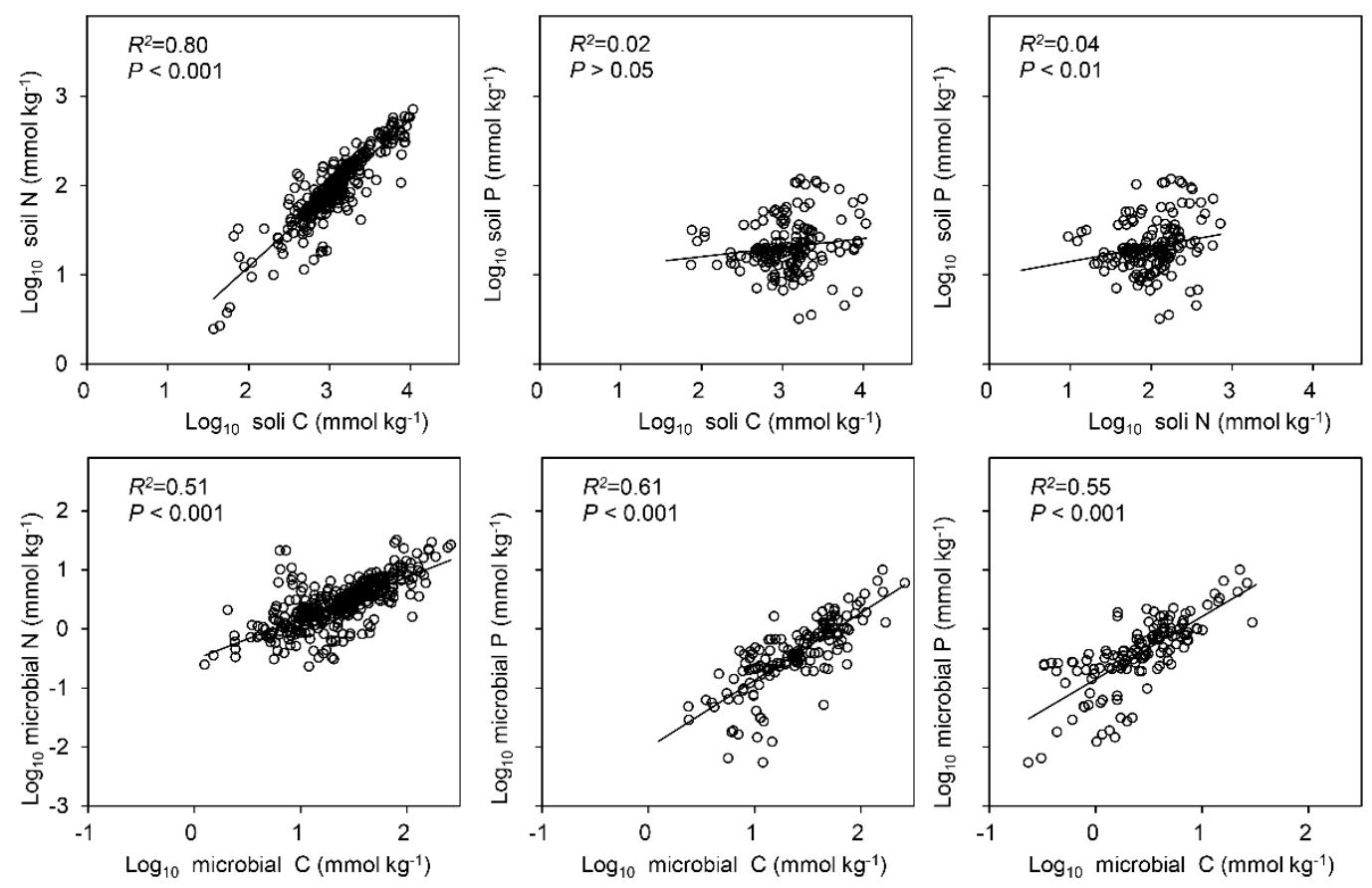

Figure 3. Relationships among $\mathrm{C}, \mathrm{N}$ and $\mathrm{P}$ in the soil and the soil microbial biomass.

\subsection{Homeostasis Characteristics of Soil Microbial Biomass C, N and P}

The concentrations of soil microbial C, N,P, C:N, C:P and N:P significantly increased as the elemental concentrations increased in the soil (see Figures S1-S5). In general, the degree of stoichiometric homeostasis for soil microbes encompassed a wide range, from non-homeostasis to strict homeostasis (see Table 3). For single elements, most of the soil microbe's $H$ values ranged from 1.01 to 5.00, with the exception of small portions that displayed strict homeostasis or non-homeostasis. For elemental ratios, most of the soil microbe's $H$ values displayed strict homeostasis, indicating that the homeostasis of soil microbial C:N, C:P and N:P displayed strong homeostasis.

Table 3. Homeostatic regulation coefficients $(H)$ for soil microbial biomass $C, N$ and $\mathrm{P}$, and C:N, C:P and N:P ratios in grassland, forest, cropland, wetland and desert.

\begin{tabular}{ccccccc}
\hline Biomes & $\boldsymbol{H}_{\mathbf{C}}$ & $\boldsymbol{H}_{\mathbf{N}}$ & $\boldsymbol{H}_{\mathbf{P}}$ & $\boldsymbol{H}_{\mathbf{C : N}}$ & $\boldsymbol{H}_{\mathbf{C}: \mathbf{P}}$ & $\boldsymbol{H}_{\mathbf{N}: \mathbf{P}}$ \\
\hline Grassland & 3.33 & 5.00 & 1.33 & Strictly $H$ & Strictly $H$ & Strictly $H$ \\
Forest & 1.89 & 1.67 & 1.54 & Strictly $H$ & Strictly $H$ & Strictly $H$ \\
Cropland & 1.01 & 1.23 & 1.29 & Strictly $H$ & 2.27 & Strictly $H$ \\
Wetland & 1.03 & $<1.00$ & 2.27 & 1.67 & Strictly $H$ & 2.17 \\
Desert & Strictly $H$ & Strictly $H$ & - & $<1.00$ & - & - \\
\hline
\end{tabular}

If the regression relationship was non-significant $(p>0.1)$, the homeostatic regulation coefficients $(H)$ for soil microbial element or element ratios were considered "strictly homeostatic". The linearized analysis using log-transformed data were shown by Figures A1-A5. 
The degree of homeostasis for soil microbial biomass $\mathrm{C}, \mathrm{N}$ and $\mathrm{P}$ differed among different biomes (see Table 3, Figures S1-S5). In grassland, the $H$ values of soil microbial biomass $C, N$ and $P$ were 3.33 , 5.00 and 1.54, respectively. In forest, the $H$ values of soil microbial biomass $\mathrm{C}, \mathrm{N}$ and $\mathrm{P}$ were weakly plastic, with values of $1.89,1.67$ and 1.54 , respectively. In cropland, the $H$ values of soil microbial biomass $\mathrm{C}, \mathrm{N}$ and $\mathrm{P}$ were plastic, with values of 1.01 and 1.23 , respectively. In wetland, $H_{\mathrm{C}}$ and $H_{\mathrm{N}}$ were plastic, while $H_{\mathrm{P}}$ showed weak homeostasis $\left(H_{\mathrm{P}}=2.27\right)$. In desert, $H_{\mathrm{C}}$ and $H_{\mathrm{N}}$ displayed strict homeostasis, while the $H_{\mathrm{C}: \mathrm{N}}$ value was less than 1.

\section{Discussion}

\subsection{The "Redfield-Like" Ratio Exists for Soil C, N and P and Soil Microbial Biomass C, N and P in Terrestrial Ecosystems in China}

Based on a detailed analysis of the data, we indicate that, in the 0-20-cm soil layer, the "Redfield-like" ratios exist for both the soil and the soil microbial biomass C:N:P in terrestrial ecosystems in China. The result is similar to previous studies that reported the "Redfield-like" ratio exists in the $0-10 \mathrm{~cm}$ soil profile $[4,5,7]$. However, we found lower soil C:N (12.2), C:P (62.8) and N:P (5.4) ratios than that at the global scale (Table 4). The different results may relate to the following two reasons. First, the data in our study only included research from China, while the data in other studies was extracted from global research; although C:N:P ratios are relatively consistent, they might change with the change of environmental factors. Secondly, the sampling depth used in our study was different from the sampling depth in the studies at the global scale (i.e., $0-20 \mathrm{~cm}$ vs. $0-10 \mathrm{~cm}$ ). The different study results indicate that soil elemental ratios decreased with soil depth because of the rapid decline in $\mathrm{C}$ and $\mathrm{N}$ with soil depth, in contrast to the similar concentrations of soil P content within the whole soil layer [5].

Table 4. Atomic (molar) nutrient ratios in the microbial biomass and total soil element pools, compared to other "Redfield-like" ratios.

\begin{tabular}{cccccc}
\hline Study Area & C:N & C:P & N:P & C:N:P & References \\
\hline Soil & & & & & \\
Global & $14.3 \pm 0.5^{*}$ & $186.0 \pm 12.9^{*}$ & $13.1 \pm 0.8^{*}$ & $186: 13: 1$ & Cleveland \& Liptzin (2007) \\
China & $14.4 \pm 0.4^{*}$ & $136 \pm 11^{*}$ & $9.3 \pm 0.7^{*}$ & $134: 9: 1$ & Tian et al. (2010) \\
Global & $16.4^{*}$ & $286.5^{*}$ & $17.5^{*}$ & $287: 17: 1$ & Xu et al. (2013) \\
China & 12.2 & 62.8 & 5.4 & $66: 5: 1$ & This study \\
\hline Microbial biomass & & & & \\
Global & $8.6 \pm 0.3$ & $59.5 \pm 3.6$ & $6.9 \pm 0.4$ & $60: 7: 1$ & Cleveland \& Liptzin (2007) \\
Global & $7.6^{*}$ & $42.4^{*}$ & $5.6^{*}$ & $42: 6: 1$ & Xu et al. (2013) \\
China & 8.7 & 64.0 & 7.6 & $66: 8: 1$ & This study \\
\hline
\end{tabular}

${ }^{*}$ Significant at 0.05 probability level associated with the one sample t-tests comparing our study to the microbial biomass and soil element ratios of previous studies. Data for China are included in the global data.

Moreover, we find lower soil C:N, C:P and N:P ratios compared to those reported in another study in China (see Table 4). We attribute this discrepancy to the data sources. The data of Tian et al. (2010) were collected from a national soil survey from the 1990s, and the soil properties have changed considerably since then due to industrialization, fertilization and climate change [20]. Specifically, the soil C and N content decreased at a temporal scale, they are lower than what was reported in the 1990s (soil C 1047 vs. $2047 \mathrm{mmol} \mathrm{kg}^{-1}$, soil N 110 vs. $134 \mathrm{mmol} \mathrm{kg}^{-1}$ ), while the soil P concentration is close to that reported in the 1990s (23 vs. 25), which results in lower soil C:N, C:P and N:P ratios in our study.

We also find that the soil microbial biomass C:N:P ratio (66:8:1) is similar to the ratio found in soil (66:5:1), and the same pattern is also observed in marine water, suggesting that the similar elemental ratios were derived by the close relationship between soil environment and soil microbes. However, our result is different from the study that took place at the global scale, which indicates that there is a great difference between the C:N:P ratio in the soil and in the soil microbial biomass (see Table 4). We attribute this discrepancy to the scale of the study, the soil and soil microbial biomass C:N:P have 
larger spatial heterogeneity (soil C:N:P 64:5:1 $\div 1030: 33: 1$ vs. 46:4:1 $\div$ 85:7:1 in our study; soil microbial biomass C:N:P 31:4:1 $\div 100: 11: 1$ vs. 56:6:1 $\div$ 82:9:1 in our study) at the global scale, which complicates the analysis of the relationship between soil microbes and the soil environment.

Furthermore, we indicate that the coupling effect of soil C and $\mathrm{N}$ is stronger than soil $\mathrm{C}$ and $\mathrm{P}$, and soil $\mathrm{N}$ and $\mathrm{P}$ (see Figure 2), the same result has been reported in other studies [4,9]. The soil P is mainly derived from the weathering effect on soil parent materials [21], which is easily and largely affected by unstable climate change, while the soil $\mathrm{C}$ and $\mathrm{N}$ mainly originate from the stable fixation of vegetation [22].

\subsection{Factors Influencing $C, N$ and $P$ Ratios in the Soil and Soil Microbial Biomass}

Climate is an important factor influencing soil and soil microbial C, N and P and the interactions between them [7,9]. In China, from south to north, the ecosystems are tropical, subtropical, warm temperate, temperate and cold temperate zones, as well as a special plateau climate zone. From east to west, there are three distinct precipitation lines (i.e., $800 \mathrm{~mm}, 400 \mathrm{~mm}$ and $200 \mathrm{~mm}$ ) with gradually decreasing precipitation, and this results in various soil $\mathrm{C}, \mathrm{N}$ and $\mathrm{P}$ concentrations in different areas (see Table 1). Although the spatial distribution of the soil C, N and P concentrations varied considerably, the change in elemental ratios in soil was limited with increasing latitude and longitude (see Table 2; Figure 4 and Figure S6), which agrees with previous studies [5-7].
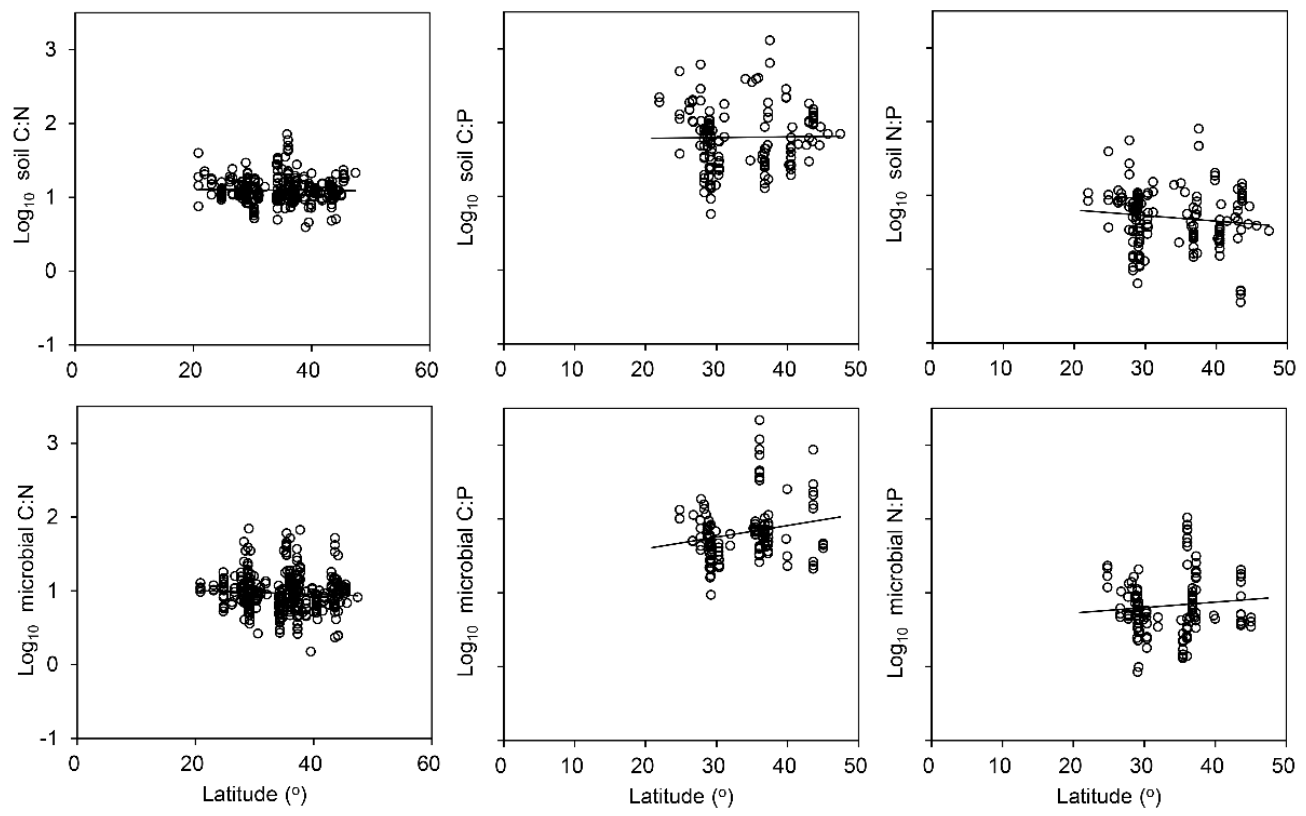

Figure 4. Latitudinal patterns of $\mathrm{C}: \mathrm{N}, \mathrm{C}: \mathrm{P}, \mathrm{N}: \mathrm{P}$ ratios in the soil and in soil microbial biomass, all significance levels were $p>0.05$.

We find that the soil microbial C:P and N:P ratios at the national scale are stable with increases in latitude, which is different from the previous studies which cover the global data [5-7]. Theoretically, in the low-latitude region, the concentration of soil P declines because of the increased P-leaching rate that results from high temperature and precipitation [23]; in contrast, the concentrations of soil C and $\mathrm{N}$ increase because of the higher production in the tropical and subtropical ecosystems, which leads to higher C:P and N:P ratios in the low-latitude region. Similarly, in the high-latitude region, the concentrations of $\mathrm{C}$ and $\mathrm{N}$ decrease in response to poor vegetation productivity, while the concentration of $P$ increases because of the lower amount of leaching caused by drought and colder conditions; this causes lower C:P and N:P ratios in the high-latitude region. In our study, there was approximately a $30^{\circ}$ maximum difference between the north and the south latitude; however, our findings do not support the abovementioned theory, suggesting that the influences of temperature and precipitation 
on the stoichiometric relationships among $\mathrm{C}, \mathrm{N}$ and $\mathrm{P}$ in the soil and in soil microbial biomass are limited in China.

The $\mathrm{C}, \mathrm{N}$ and $\mathrm{P}$ concentrations both in the soil and soil microbial biomass decreased with an increase in $\mathrm{pH}$ (see Figure 5). This is mainly because of the composition of the soil microbial community structure: bacteria and actinobacteria grow better in slightly alkaline environments, while most fungi prefer acidic soil $(\mathrm{pH}<5)$ [24], and different microbial species require different nutrient elements. The $\mathrm{pH}$ of soil has been regarded as an important controlling factor for the growth of soil microbial communities [25], with significant effects on $\mathrm{C}, \mathrm{N}$ and $\mathrm{P}$ concentrations in the soil microbial biomass. Similar to previous studies, we also find that the effects of the $\mathrm{pH}$ value on the C:N:P ratio in the soil and soil microbial biomass are not significant (see Figure 6), physical factors weakly controlled the soil microbial biomass elemental ratios.
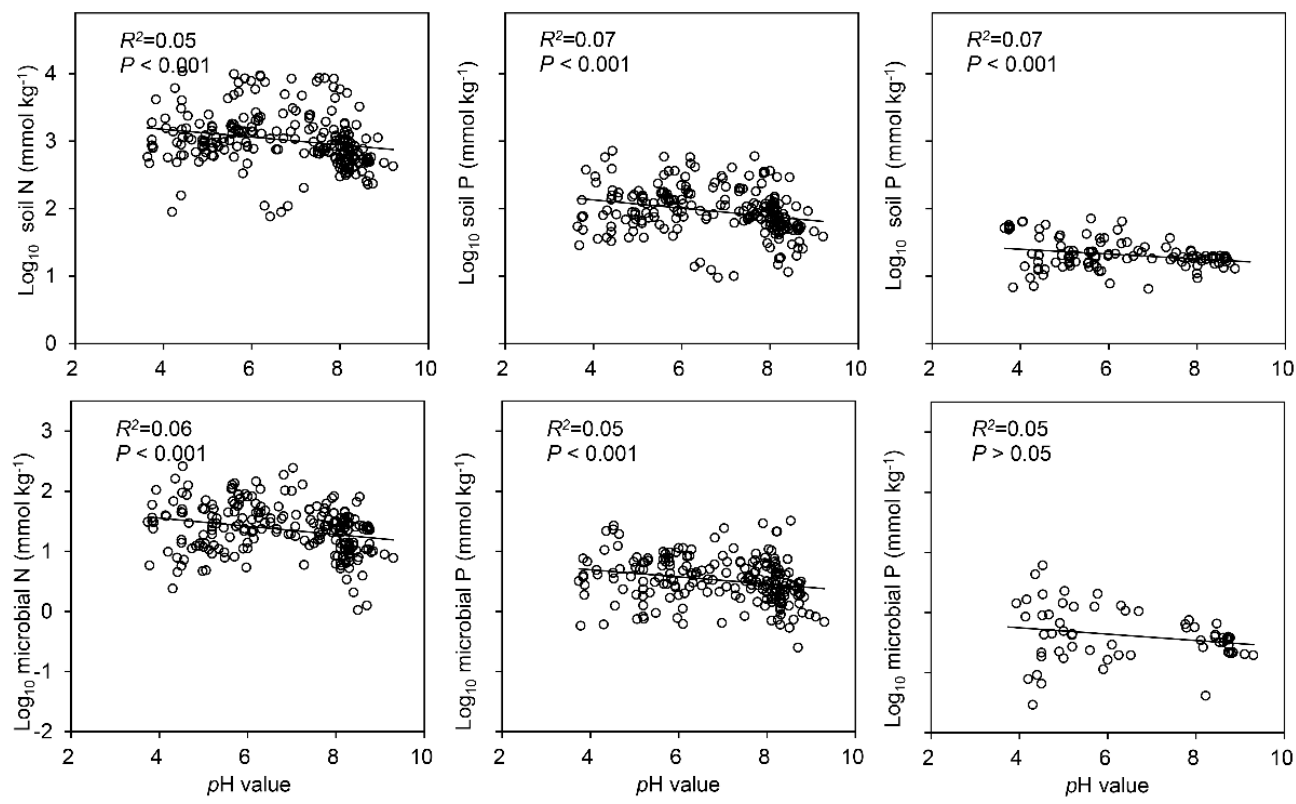

Figure 5. Relationship between $\mathrm{pH}$ and concentrations of $\mathrm{C}, \mathrm{N}, \mathrm{P}$ in the soil and soil microbial biomass.
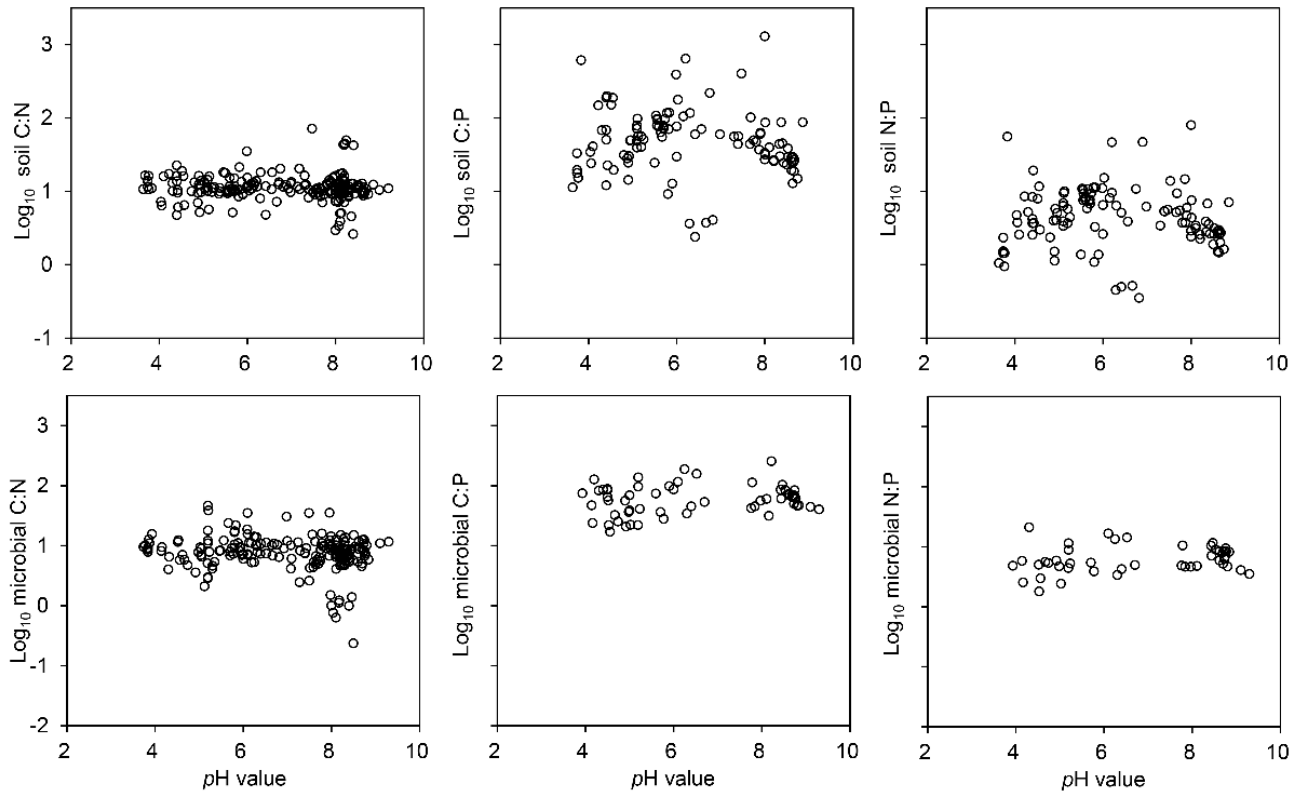

Figure 6. Relationships between $\mathrm{pH}$ value and C:N:P ratio in the soil and soil microbial biomass. Those with significant relationships were plotted with a regression line. 


\subsection{Soil Microbial Biomass N:P Ratio Can Be Used as Nutrient Limitation Indicator}

Many previous studies have used the N:P "breakpoint" in leaves to determine nutrient limitation [26-28]: N:P $>16$ systems are hypothesized to be P-limited and N:P $<14$ systems are hypothesized to be N-limited. There has been numerous field experiments having proved the use of $\mathrm{N}: \mathrm{P}<14$ to determine $\mathrm{N}$-limited, while few studies proved the use of $\mathrm{N}: \mathrm{P}>16$ to determine P-limited. On the contrary, one study stated that $\mathrm{N}: \mathrm{P}>16$ is not appropriate to determine P-limitation [29]. Moreover, Chen et al. (2013) measured the $\mathrm{N}$ and $\mathrm{P}$ content in plants across eastern China, and showed that $\mathrm{N}: \mathrm{P}$ in leaves was unstable and easily driven by environmental factors [30].

Compared to N:P in plants, the N:P ratio in soil microbial biomass is relatively consistent and displays stability under the condition of habitat heterogeneity and climate change (see Tables 2 and 3 , Figure 4, Figure 6 and Figure S6), implying that the soil microbial biomass N:P ratio estimated in our study (i.e., 6.7) can be regarded as the nutrient limitation indicator. In fact, Cleveland and Liptzin (2007) also have put forward the suggestion that soil microbial N:P ratios (6.9) can be included as nutrient P-limitation indicators. For example, Townsend et al. (2007) conducted their study in the tropical rain forest in Puerto Rico with great climate changes and P deficiency [29]. The N:P ratio in different plant individuals varies largely, therefore, the leaf N:P "breakpoint" is inappropriate. However, the N:P ratio in soil microbial biomass is relatively stable with the change of soil environment (see Figures 4 and 6), using the N:P ratio in soil microbial biomass can bring about better results (using the N:P ratio data in Table 4 as the basis, either 6.9 in the previous study or 6.7 in our study indicates P-limitation), and the greater the N:P ratio is, the more serious the P-limitation is. On the basis of the above considerations, we support the suggestion of Cleveland and Liptzin (2007) [4], and also suggest that the N:P ratio in the soil microbial biomass also should be included to judge the nutrient limitation within ecosystems.

\subsection{Evaluation of the Stoichiometric Homeostasis of Soil Microbial Biomass C, N and P in Terrestrial Ecosystems in China}

Ecological stoichiometry has assumed the plastic homeostasis for plants and the strict homeostasis for animals; in contrast, microbes fall somewhere in the middle [3]. However, a meta-analysis study indicated that the homeostasis for organisms was complicated [19]. Our study showed that the stoichiometric homeostasis of soil microbes presented a wide range from non-homeostasis to strict homeostasis. The $H$ values of soil microbial biomass $\mathrm{C}, \mathrm{N}$ and $\mathrm{P}$ as single elements ranged from 1.01 to 5.00 , with the exception of small portions that were strictly homeostatic or non-homeostatic; our values were weaker than those in freshwater zooplankton quantified by Karimi and Folt (2006) $\left(H_{\mathrm{C}}, H_{\mathrm{N}}\right.$ and $H_{\mathrm{P}}$ were 13.8, 34.1 and 7.7, respectively) [14] and were also weaker than those reported in plants (with an average value of 5.60) [16]. For soil microbial biomass C:N, C:P and N:P, the values of $H$ mainly displayed strict homeostasis, which is similar to the values of animals quantified by Jeyasingh et al. (2009) ( $H_{\mathrm{C}: \mathrm{P}}$ for Daphnia ranged from 16 to 161, with strict homeostasis) but stronger than those of plants $\left(H_{\mathrm{N}: \mathrm{P}} 1.7-4.6\right)$ [18]. Overall, it appears that the $H$ of soil microbial biomass $\mathrm{C}, \mathrm{N}$ and $\mathrm{P}$ is weak, perhaps because the soil microbial composition is more complicated than in animals and plants [3]. However, the $H$ of soil microbial C:N, C:P and N:P displayed strict homeostasis, which is higher than the corresponding $H_{\mathrm{C}}, H_{\mathrm{N}}$, and $H_{\mathrm{P}}$ values; this result is consistent with the study on plants [6] and may be related to the strong coupling interaction between major elements.

Soil microbes of different ecosystems exhibit different $H$ values. This is likely because of differences in soil microbial composition and structure among different biomes. The result is similar to the study on the stoichiometric homeostasis of vascular plants, which reported that different plant functional communities displayed different homeostasis [16]. The study suggests that ecosystems which include more homoeostatic species will present stronger homoeostasis, higher stability and greater function, so we infer that the stronger homeostasis is probably due to the soil microbial community being dominated by more homoeostatic species. The soil microbial community is composed of various species, including bacteria, fungi, actinobacteria, algae and some protozoa, and the demand for proteins and nucleotides varies among these, as well as the physiological function of the membrane structures, which leads to 
various levels of homeostasis [24]. For example, most of the marine bacteria's $H$ values were greater than 6, with a small portion having especially large $H$ values [13]; on the contrary, the values of $H$ for algae and fungi were relatively low (H 1-2) [31].

In addition, there are many other factors that can influence $H$. A previous study summarized the factors that appear to influence homeostasis, including growth rate and a variety of biotic and abiotic factors [19]. A study focused on the diatom Cyclotella indicated that the values of $H_{\mathrm{N}: \mathrm{P}}$ will increase with the increase of growth rate [32]. Furthermore, a study on the homeostasis of vascular plants in an Inner Mongolian grassland showed that the life forms and the nutrient utilization strategy can have major effects on homeostasis; in fact, plants within the same functional community had similar homeostasis, whereas plants in different functional communities displayed different homeostasis, and the $H$ values of plants varied according to differences in species, growth stages and organs $[6,16]$. At present, few studies have paid attention to the effect of such factors on soil microbial biomass stoichiometric homeostasis, so this field requires further investigation.

Stoichiometric homeostasis helps us to understand the observed variation in the ratio of $\mathrm{C}, \mathrm{N}$ and $\mathrm{P}$ in soil microbial biomass [3]. For soil microbes, the composition is complex and variable. However, the compositions of soil microbes integrate as a whole-organism to maintain soil microbial biomass elemental concentrations in the environment. There have been some studies which also focused on the whole-organism's stoichiometric homeostasis at biome and global scales, and suggest that aggregated community stoichiometric homoeostasis can help us to understand the stability and function of ecosystems [4-6]. Therefore, we simplified the soil microbes as a whole-organism or a group to quantify the degree of stoichiometric homeostasis. Further studies are necessary to study both the stoichiometric homeostasis of soil microbial species and the role each species plays in the homeostasis of the soil microbial community. This would enable us to fully understand the stoichiometric homeostasis of soil microbes.

\section{Conclusions}

A highly constrained soil microbial biomass C:N:P ratio of 66:8:1 was found in the $0-20 \mathrm{~cm}$ soil layer, which was close to the atomic soil C:N:P ratio (66:5:1) in terrestrial ecosystems in China. The influences of temperature and precipitation on stoichiometric relationships among $\mathrm{C}, \mathrm{N}$ and $\mathrm{P}$ in the soil and soil microbial biomass are limited in China; however, they decrease with the increase of soil $\mathrm{pH}$. The degree of stoichiometric homeostasis for soil microbes displayed a wide range, from strict homeostasis to non-homeostasis. The homeostasis of soil microbial biomass $\mathrm{C}, \mathrm{N}$ and $\mathrm{P}$ as single elements was weaker than animals and plants, while the homeostasis of soil microbial biomass $\mathrm{C}: \mathrm{N}, \mathrm{C}: \mathrm{P}$ and N:P was close to animals. Our study is helpful for understanding the characteristics of stoichiometric homeostasis of the soil microbial biomass $\mathrm{C}, \mathrm{N}$ and $\mathrm{P}$ in China.

Given the limitations of this study that the soil microbe is simplified as a whole-organism or a group to quantify the degree of stoichiometric homeostasis, further studies are worthwhile to calculate the stoichiometric homeostasis of soil microbial species, which would enable us to determine the role each species plays in the homeostasis of the whole-organism, and detect the influencing factors on them to fully understand the stoichiometric homeostasis of soil microbes.

Supplementary Materials: The following are available online at http://www.mdpi.com/2071-1050/11/10/2804/s1, Figures S1-S5: $H$ values under grassland, forest, cropland, wetland and desert. The dotted diagonal line shows the 1:1 relationship which represents non-homeostasis. Figure S6: Longitudinal patterns of C:N, C:P, N:P ratios in the soil and in soil microbial biomass.

Author Contributions: H.X. and X.L. contributed equally. Conceptualization, H.X., X.L. and H.L.; Data collection, H.X., X.L. and Q.Z.; Formal Analysis, H.X., X.L. and Q.Z.; Original Draft Preparation, H.X. and Q.Z.; Writing-Review \& Editing, X.L. and H.L.

Funding: This study was supported by Major project of the National Social Science Fund of China (18VDL001), and the Key Program of Beijing Social Science Foundation Research Base Project (No. 18JDZGA003). 
Acknowledgments: We gratefully acknowledge the students and teachers who have ever helped us, and also thank the anonymous reviewers for presenting valuable suggestions to improve this paper. Xin Li of Tsinghua University kindly improved our English.

Conflicts of Interest: The authors declare no conflict of interest. The funders had no role in the design of the study; in the collection, analysis or interpretation of data; in the writing of the manuscript, or in the decision to publish the results.

\section{Appendix A}
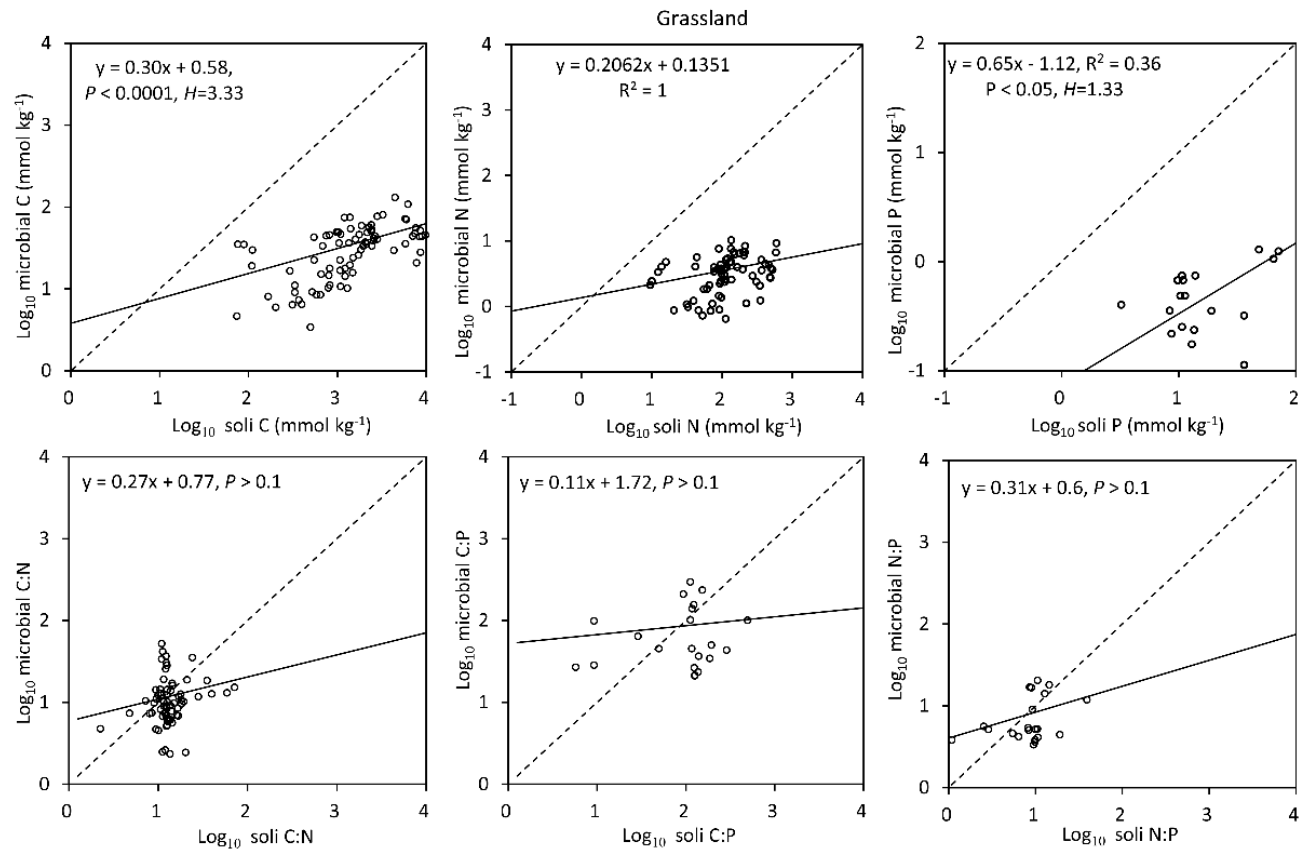

Figure A1. $H$ values under grassland. The dotted diagonal line shows the 1:1 relationship which represents non-homeostasis.
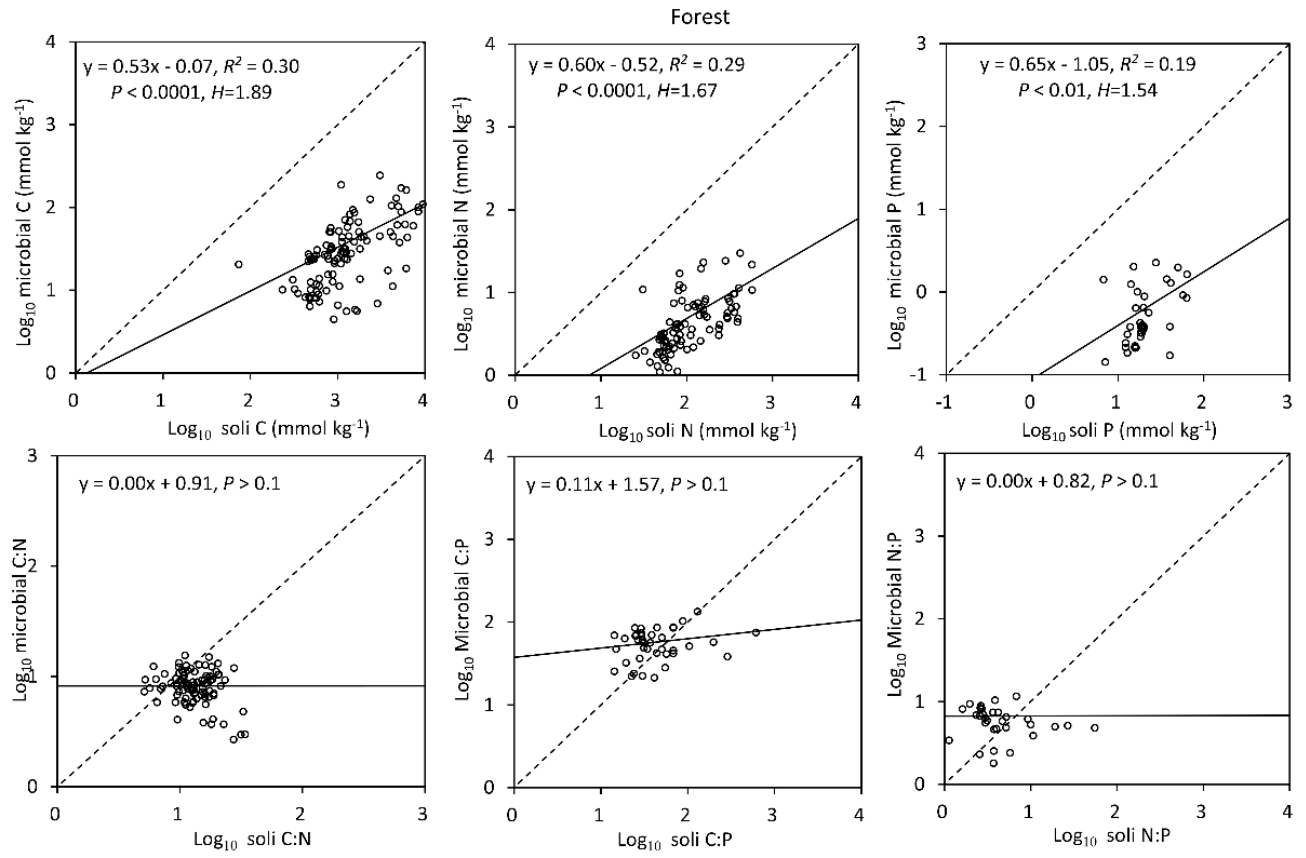

Figure A2. $H$ values under forest. The dotted diagonal line shows the 1:1 relationship which represents non-homeostasis. 

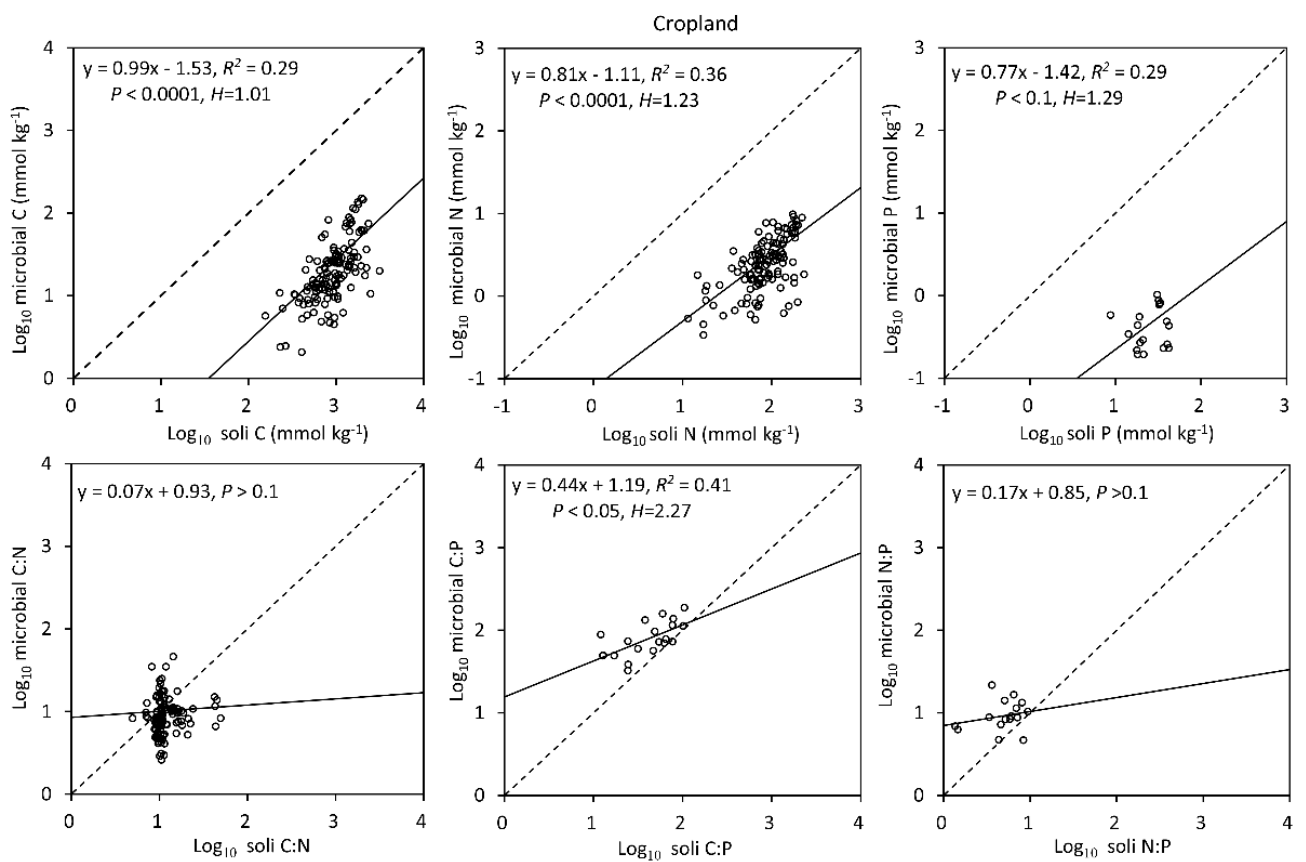

Figure A3. $H$ values under cropland. The dotted diagonal line shows the 1:1 relationship which represents non-homeostasis.
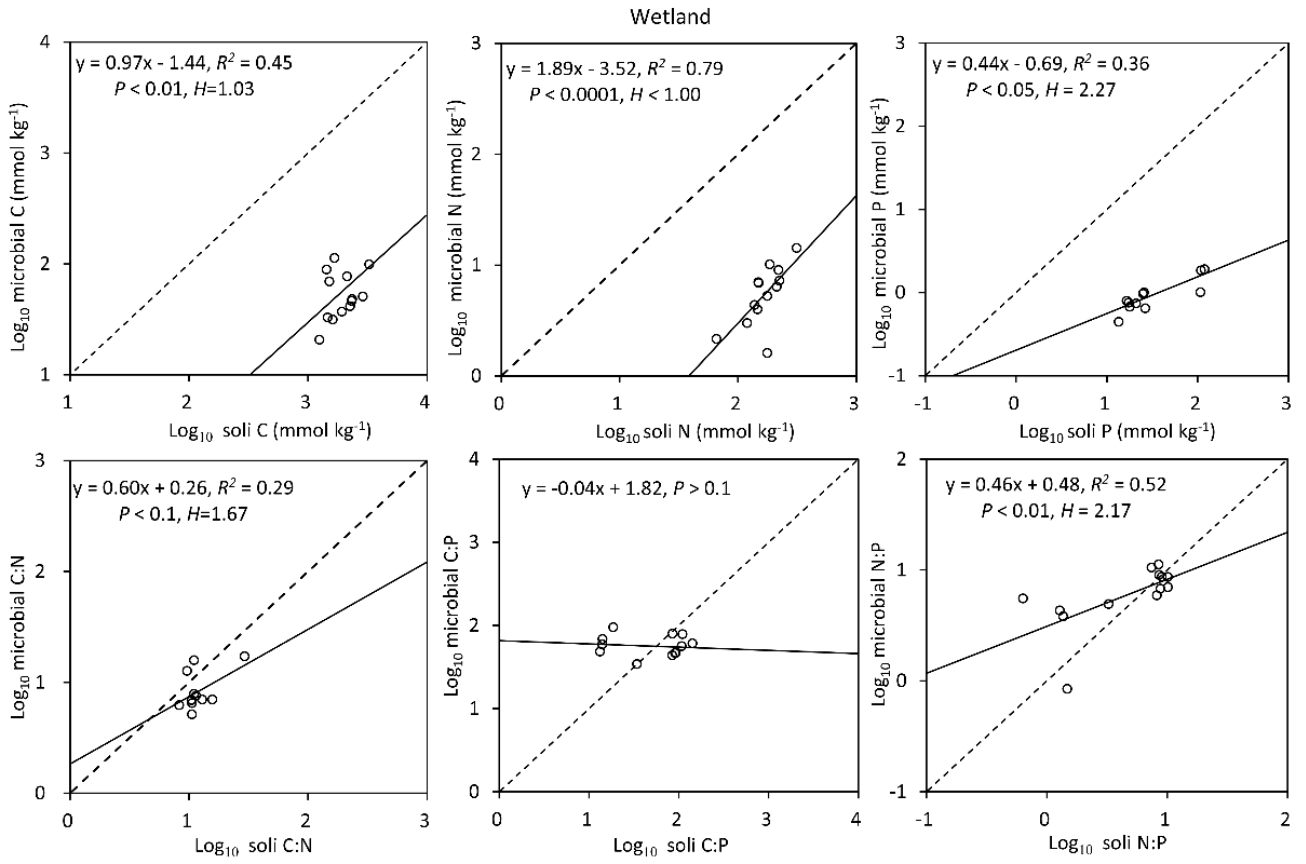

Figure A4. $H$ values under wetland. The dotted diagonal line shows the 1:1 relationship which represents non-homeostasis. 

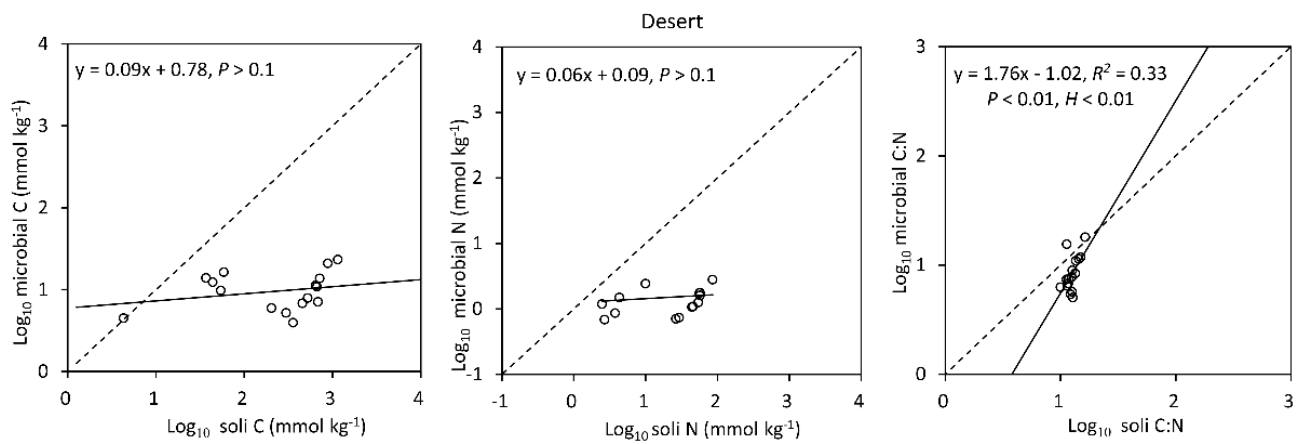

Figure A5. $H$ values under desert. The dotted diagonal line shows the 1:1 relationship which represents non-homeostasis.
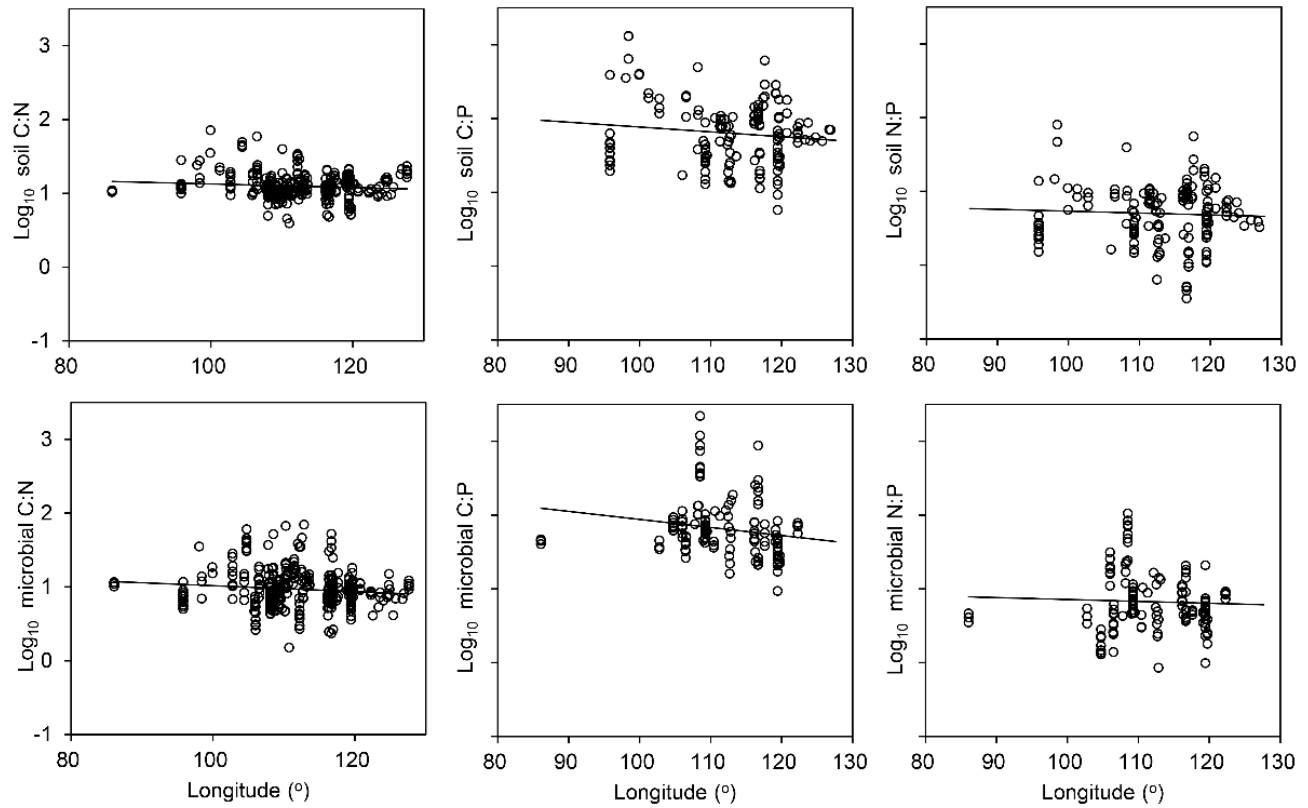

Figure A6. Longitudinal patterns of C:N, C:P, N:P ratios in the soil and in soil microbial biomass.

\section{References}

1. Redfield, A.C. The biological control of chemical factors in the environment. Am. Sci. 1958, 46, $205-221$.

2. Field, C.B.; Behrenfeld, M.J.; Randerson, J.T.; Falkowski, P. Primary production of the biosphere: Integrating terrestrial and oceanic components. Science 1998, 281, 237-240. [CrossRef]

3. Sterner, R.W.; Elser, J.J. Ecological Stoichiometry, the Biology of Elements from Molecules to the Biosphere; Princeton University Press: Princeton, NJ, USA, 2002.

4. Cleveland, C.C.; Liptzin, D. C:N:P stoichiometry in soil, is there a "Redfield ratio" for the microbial biomass? Biogeochemistry 2007, 85, 235-252. [CrossRef]

5. Tian, H.; Chen, G.; Zhang, C.; Melillo, J.M.; Hall, C.A.S. Pattern and variation of C:N:P ratios in China's soils, a synthesis of observational data. Biogeochemistry 2010, 98, 139-151. [CrossRef]

6. Yu, Q.; Elser, J.J.; He, N.; Wu, H.; Chen, Q.; Zhang, G.; Han, X. Stoichiometric homeostasis of vascular plants in the Inner Mongolia grassland. Oecologia 2011, 166, 1-10. [CrossRef] [PubMed]

7. Xu, X.; Thornton, P.E.; Post, W.M. A global analysis of soil microbial biomass carbon, nitrogen and phosphorus in terrestrial ecosystems. Glob. Ecol. Biogeogr. 2013, 22, 737-749. [CrossRef]

8. Li, P.; Yang, Y.; Han, W.; Fang, J. Global patterns of soil microbial nitrogen and phosphorus stoichiometry in forest ecosystems. Glob. Ecol. Biogeogr. 2014, 23, 979-987. [CrossRef]

9. Fanin, N.; Fromin, N.; Barantal, S.; Stephan, H. Stoichiometric plasticity of microbial communities is similar between litter and soil in a tropical rainfores. Sci. Rep. 2017, 7, 12498. [CrossRef] 
10. Wright, C.J.; Coleman, D.C. Cross-site comparison of soil microbial biomass, soil nutrient status, and nematode trophic groups. Pedobiologia 2000, 44, 2-23. [CrossRef]

11. Hessen, D.O. Too Much Energy? Ecology 2004, 85, 1177-1178. [CrossRef]

12. Rhee, G.Y. Effects of N, P atomic ratios and nitrate limitation on algal growth, cell composition and nitrate uptake. Limnol. Oceanogr. 1978, 23, 10-25. [CrossRef]

13. Makino, W.; Cotner, J.B.; Sterner, R.W.; Elser, J.J. Are bacteria more like plants or animals? Growth rate and resource dependence of bacterial C:N:P stoichiometry. Funct. Ecol. 2003, 17, 121-130. [CrossRef]

14. Karimi, R.; Folt, C.L. Beyond macronutrients: Element variability and multielement stoichiometry in freshwater invertebrates. Ecol. Lett. 2006, 9, 1273-1283. [CrossRef] [PubMed]

15. Jeyasingh, P.D.; Weider, L.J.; Sterner, R.W. Genetically-based trade-offs in response to stoichiometric food quality influence competition in a keystone aquatic herbivore. Ecol. Lett. 2009, 12, 1229-1237. [CrossRef]

16. Yu, Q.; Chen, Q.; Elser, J.J.; He, N.; Wu, H.; Zhang, G.; Wu, J.; Bai, Y.; Han, X. Linking stoichiometric homeostasis with ecosystem structure, functioning, and stability. Ecol. Lett. 2010, 13, 1390-1399. [CrossRef]

17. Demott, W.R.; Pape, B.J. Stoichiometry in an ecological context: Testing for links between Daphnia P-content, growth rate and habitat preference. Oecologia 2005, 142, 20-27. [CrossRef]

18. Güsewell, S. N:P ratios in terrestrial plants: Variation and functional significance. New Phytol. 2004, 164, 243-266. [CrossRef]

19. Persson, J.; Fink, P.; Goto, A.; Hood, J.M.; Jonas, J.; Kato, S. To be or not to be what you eat: Regulation of stoichiometric homeostasis among autotrophs and heterotrophs. Oikos 2010, 119, 741-751. [CrossRef]

20. Yue, K.; Fornara, D.A.; Yang, W.; Peng, Y.; Li, Z.; Wu, F.; Peng, C.H. Effects of three global change drivers on terrestrial C:N:P stoichiometry: A global synthesis. Glob. Chang. Biol. 2017, 23, 2450-2463. [CrossRef]

21. Walker, T.W.; Adams, A.F.R. Studies on soil organic matter. Soil Sci. 1958, 85, 307-318. [CrossRef]

22. Vitousek, P.M. Nutrient Cycling and Limitation, Hawai'i as a Model System; Princeton University Press: Princeton, NJ, USA, 2004.

23. Zhang, C.; Tian, H.; Liu, J.; Wang, S.; Liu, M.; Pan, S.; Shi, X. Pools and distributions of soil phosphorus in China. Glob. Biogeochem. Cycle 2005, 19, GB1020. [CrossRef]

24. Hu, Y.; Wang, S.; Yan, S. Research advances on the factors influencing the activity and community structure of soil microorganism. Chin. J. Soil Sci. 2006, 37, 170-176, (In Chinese with English Abstract).

25. Xu, M.; Li, X.; Cai, X.; Gai, J.; Li, X.; Christie, P.; Zhang, J. Soil microbial community structure and activity along a montane elevational gradient on the Tibetan Plateau. Eur. J. Soil Biol. 2014, 64, 6-14. [CrossRef]

26. Aerts, R.; Chapin, F.S. The mineral nutrition of wild plants revisited, A re-evaluation of processes and patterns. Adv. Ecol. Res. 2000, 30, 1-67.

27. Cleveland, C.C.; Townsend, A.R.; Schmidt, S.K. Phosphorus limitation of microbial processes in moist tropical forests, evidence from short-term laboratory incubations and field experiments. Ecosystems 2002, 5, 680-691. [CrossRef]

28. Reich, P.B.; Oleksyn, J. Global patterns of plant leaf $\mathrm{N}$ and $\mathrm{P}$ in relation to temperature and latitude. Proc. Natl. Acad. Sci. USA 2004, 101, 11001-11006. [CrossRef]

29. Townsend, A.R.; Cleveland, C.C.; Asner, G.P.; Bustamante, M.M. Controls over foliar N:P ratios in tropical rain forests. Ecology 2007, 88, 107-118. [CrossRef]

30. Chen, Y.; Han, W.; Tang, L.; Tang, Z.; Fang, J. Leaf nitrogen and phosphorus concentrations of woody plants differ in responses to climate, soil and plant growth form. Ecography 2013, 36, 178-184. [CrossRef]

31. Sterner, R.W.; Clasen, J.; Lampert, W.; Weisse, T. Carbon:phosphorus stoichiometry and food chain production. Ecol. Lett. 1998, 1, 146-150. [CrossRef]

32. Shafik, H.M.; Herodek, S.; Presing, M.; Voros, L.; Balogh, K.V. Growth of Cyclotella meneghiniana Kutz. II. Growth and cell composition under different growth rates with different limiting nutrient. Ann. Limnol. Int. J. Liml. 1997, 33, 223-233. [CrossRef]

(C) 2019 by the authors. Licensee MDPI, Basel, Switzerland. This article is an open access article distributed under the terms and conditions of the Creative Commons Attribution (CC BY) license (http://creativecommons.org/licenses/by/4.0/). 